\title{
sciendo
}

CIVIL AND ENVIRONMENTAL ENGINEERING REPORTS

E-ISSN 2450-8594

CEER 2021; 31 (3): 0085-0098

DOI: $10.2478 /$ ceer-2021-0035

Original Research Article

\section{DEPENDENCE OF UNDERGROUND INFRASTRUCTURE AND LAND MANAGEMENT IN URBANIZED AREAS}

\author{
Barbara KSIT ${ }^{1}$, Roman PILCH ${ }^{2}$ \\ ${ }^{1}$ Poznań University of Technology, Faculty of Civil and Transport Engineering \\ ${ }^{2}$ Poznań University of Technology, Faculty of Architecture
}

\begin{abstract}
The article presents a current view on the issue of supplying utilities to land regarded differently than merely technical solutions. The authors offer an insight to the issue of the technical supplying of urbanized areas, treating such infrastructure as a determinant of the coexistence of buildings and transfigurations of the urban fabric. Using selected examples of novel means of identifying existing solutions of the underground technical infrastructure (canals, sewage and stormwater networks, transportation and communication tunnels, building in additional contemporary of installations of logical networks or unidentified remains of past development), the need to carry out additional analyses and prepare a new, or update-change the existing local spatial development plan were identified. It was noted that The construction of underground infrastructure corridors ought to be the key, preceding the issuing of building permits, the commencement of activities by developers as well as administrative conditions. The underground infrastructure has an influence of the dynamics as well as quality of spatial transformations of urbanized areas.
\end{abstract}

Keywords: spatial planning, development of technical infrastructure in an area, investment process, urbanistic revitalization

${ }^{1}$ Corresponding author: Poznań University of Technology, Faculty of Civil and Transport Engineering, e-mail: barbara.ksit@put.poznan.pl 


\section{REVITALIZATION OF AREASAIMED ATINTRODUCING NEW SERVICE FUNTIONS}

Expansion connected with civilizational development leads to interest being taken in areas which had once, for dozen or even hundreds of years, undeveloped. These are often the outskirts of cities, which are engulfed by expanding administrative borders of urbanized areas The evolutionary processes which accompany small suburban towns whose geographical status has led them to being classified as villages, is leading to constant natural (as it is viewed) bonding with these areas [1]. History has noted more and more such cases. Villages located a few kilometers from cities are becoming districts of these nearby cities. The newlycreated districts of urban agglomeration take on the names of the former villages to commemorate their existence. Industrial areas located on the outskirts of cities required the successive expansion of these areas along with an increase in the scale of production and its potential.

Over time, however, these areas also "approached" or even became a part of the city. New communication and transportation routes leading from cities to these industrial centers became public roads. The significance of these roads increased, from roads with a smaller number of users to public transportation routes, intended as, e.g., access routes to settlements being created along such roads. Urban streets were formed, the natural completing element of which was the laying down of underground installation systems, such as electrical, gas and sewage networks, oftentimes of large diameters [2]. These networks supplied media from industrialized areas to residential neighborhoods, e.g. collective heating pipelines and technical installation channels, which should provide constant access for inspection. Increasing volumes of sewage produced in cities were carried away using such underground systems by large diameter pipelines to newly-built sewage treatment plants, often located in such non-urban-industrial areas.

Over a period of a few dozen years, the technical condition of such underground utility systems underwent degradation. The quantity of utilities supplied to and retrieved from the city centers increased, thus new systems of technical infrastructure were built, characterized by higher throughputs, even leaving the old underground installations without their further practical application or use. As a result of the development of industrial technologies, earlier created industrial plants underwent degradation, and ultimately closed down. The remaining industrial areas are becoming, and in subsequent evolutionary transformations will continue to make, attractive areas for urban transformations [3]. Archival materials documenting, e.g.: the course of underground installations built a few years ago or inspection pits in these areas were not always, or one should say very seldom, maintained. New generations of users do not possess current information regarding what had once been in these areas. The accuracy of geodesic resources 
also leaves much to be desired when it comes to this, and formerly existing information regarding underground installations on underground installations were never introduced to updated new inventories containing geodetic descriptions of the area.

The process of getting rid of the former development sometimes results in the complete superficial demolition of buildings, and the areas, e.g. of low greenery, which form in these spaces do not possess any information in planning documents on "underground development" which had previously existed there. Carrying out new investment activities in such regions often runs the risk of encountering "surprises" found during, e.g.: earthworks without precisely identifying these areas, at least in terms of geotechnical studies [4].

Modern-day administrative procedures in the case of the lack of a current spatial development plan for a given area permit development conditions to be established via an administrative decision issued by local governments (the president of the city, mayor, voit)[Fig.1]. In such cases, as well as when administrative activities involving changes of an existing spatial development plan, are assumed, the carried out exploratory procedure does not contain information (as it turns out during the course of realizing new investment functions in post-industrial areas) regarding the signaled possibilities of former development or technical utilities occurring in a given area, which had been present or remain in this location. Selected historically documented areas of cities, e.g. old towns, are under preservation maintenance, and authorities responsible for providing such protection have been attempting to implement additional administrative solutions, e.g. the obligation to carry out archeological studies to gain more in-depth information on historical traces of human activity[Fig.2].

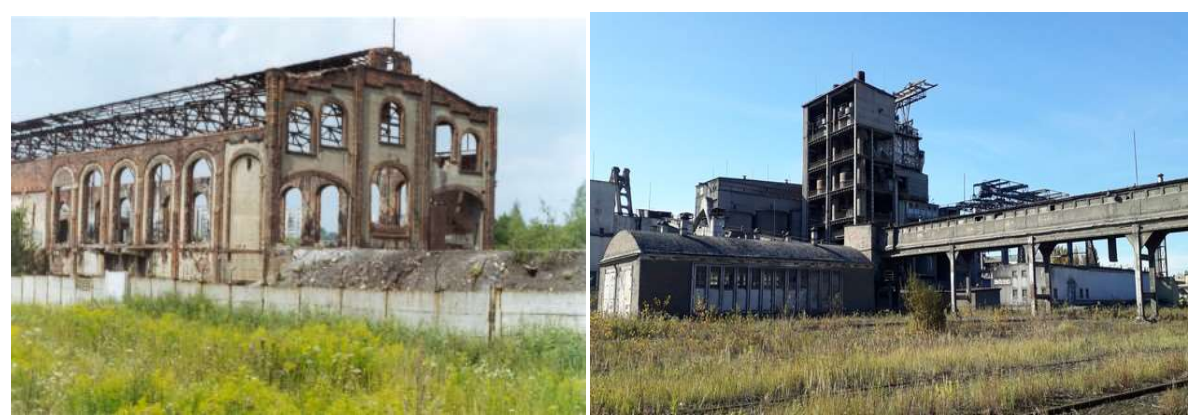

Fig.1, Fig. 2. View of post-industrial areas not in use for a few dozen years [17], [18] 


\section{GEODESIC-ENGINEERING FIELD RECONAISSANCE IN SPATIAL PLANNING}

Carried out during the reconnaissance of land prior to assuming technical-design works or construction works are, e.g.: geotechnical studies in a rather limited scope showing information that is necessary for technical-design civil engineering and construction calculations. Current methods of determining the non-invasive type of terrain are, in some cases, especially useful when it comes to determining areas the development of which should additionally call for preparing documentation formulating, graphically and descriptively, the potential remains of former utilities or structures in the ground. Among such modern discovery methods are conductometric studies and analyses [Fig.3].
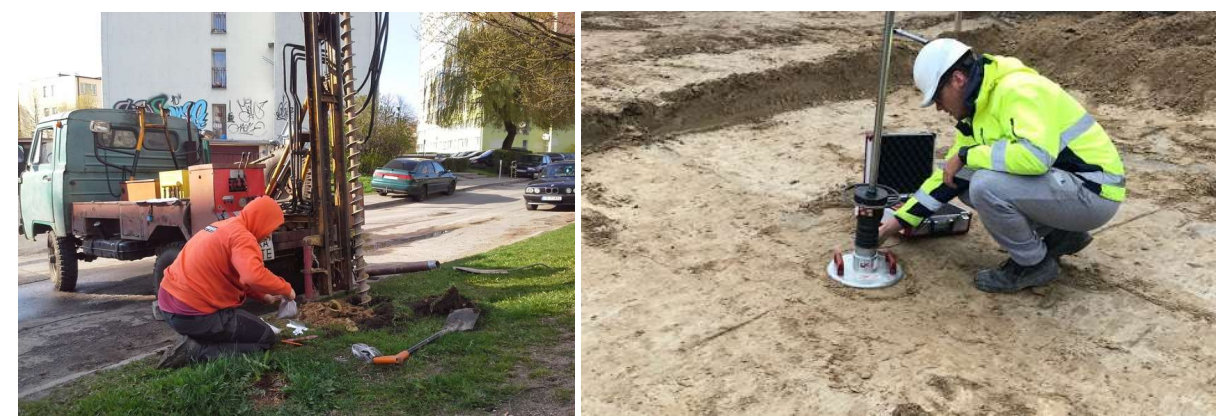

Fig.3. Example of collecting soil samples using an invasive method of geotechnical drillings Fig. 4. Simplified manner of obtaining geotechnical information on the land found directly beneath the planned development [19]

Using the technique of electrical resistance thermal imaging, information regarding the objects found underground is obtained.

The chronological order of the identified objects is determined based on relative dating, which is based on, among others, historical materials as well as trees found on the surface of the objects (ingrown in their structure) of trees[Fig.4]. As results from information published by geological and archeological communities in terms of modern non-invasive geological and archeological iventorying techniques, they lead to the development of improved identification techniques, the use of which will facilitate, among others, obtaining data which had been obtained using incidental opencast methods [5]. 


\section{GEOPHYSICAL IDENTIFICATION METHODS OF UNDERGROUND DEVELOPMENT IN URBANIZED AREAS}

Engineering geophysical studies can be applied, among others, to identify ground in terms of the underground objects contained within it, such as, e.g. foundations, walls, reinforced slabs, non-inventoried rooms and infrastructure, etc. Studies carried out using various methods and techniques allow for precisely indicating their exact location under the surface of the studied terrain, which makes it possible to determine their geometric parameters [6]. These objects, if not removed prior to the commencement of groundworks, may interfere with or even make it impossible to carry out construction works for new investments, as well as expanding existing buildings [Fig.5]. The identification of such objects also holds importance when it comes to the proper placement of load-bearing elements of building structures.

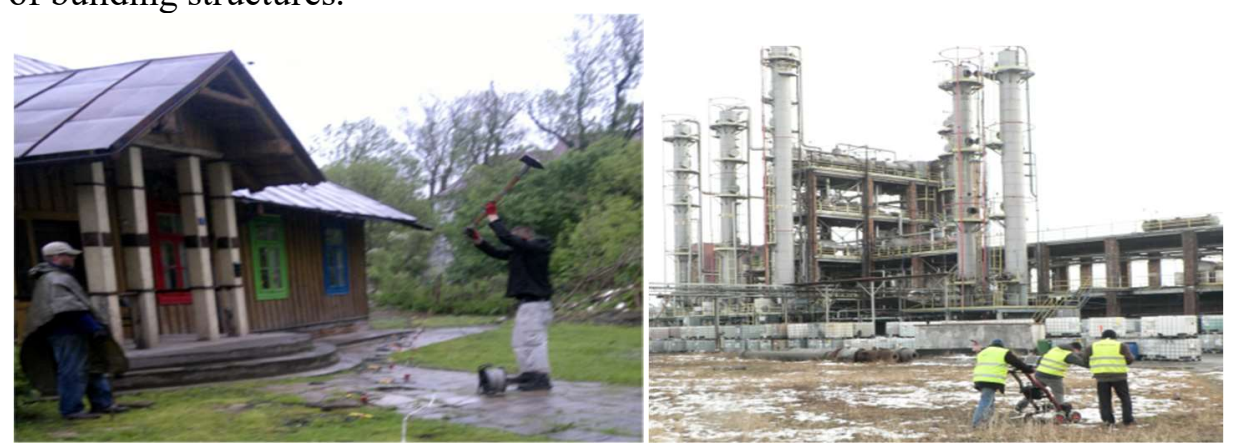

Fig. 5, Fig.6. Seismic measurement to search for underground rooms (chambers, tunnels) or their remains within the archeological site (on the left) and georadar measurement in the area of a chemical plant in an effort to identify the remains of old foundation, non-

inventorized infrastructure as well as fuel tanks, carried out of the needs of a new investment (on the right) [20]

Most frequently applied are the following geophysical methods and research techniques:

- Georadar surveying GPR,

- Georadar mapping GPR,

- Micro-seismic surveying MASW 2D,

- Electrical resistance tomography ERT 2D.

The above methods are the best at aiding the localization of underground objects, with georadar studies being the most accurate for near surface (up to a few meters) objects which are not characterized by a very large size[Fig.6.]. When dealing with greater depths and measurements of objects, microseismic monitoring has the best results [7]. 
The non-invasiveness of geophysical studies allows for cost-efficiency, saving time and high precision of identifying objects. Another branch of application of such studies is archeology, e.g. for the location of cellars, chambers, walls, tombs, tunnels and crypts [8]. Various geophysical methods area applied here, and their choice ought to be precisely adapted to the physical properties (e.g. dimensions, material which they are made of) of the objects being searched for, and the expected depth where they might be present in the analyzed medium[Fig.7]. This allows for optimizing the methodology and scope of given studies [9].

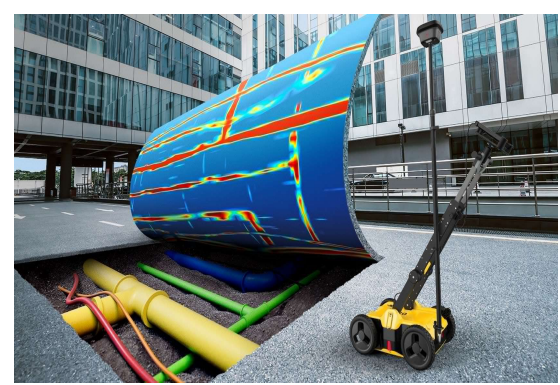

Fig.7. Georadar section for searching for unidentified objects, such as chambers, cellars and corridors, found in the area adjacent to the historic buildings. Abundant infrastructure, the remains of foundations as well as zones indicating the remains of other structures under the surface of ground can be seen [21]

\section{THE MOST FREQUENTLY ENCOUNTERED METHODS OF ENGINEERING GEOPHYSICS}

\subsection{Seismic method}

The method involves the analysis of artificially generated seismic waves in a given center. These waves, crossing through a heterogeneous center, are subjected to phenomenon, such as: breaking, reflection, diffraction. Each abnormality in the structure as well as properties of the medium (e.g. change in density, cracks, weathering, faults) influence the changes in the seismic parameters, such as the values of wave velocities or suppression[Fig.8]. This method is applied to indicate geological borders, a solid unbroken surface, e.g. granites, limestones, dolomites, etc. in quarries, discontinuities, ground water levels, changes in the density, settling phenomena, voids and karst formations, identifying underground structures[22]. 


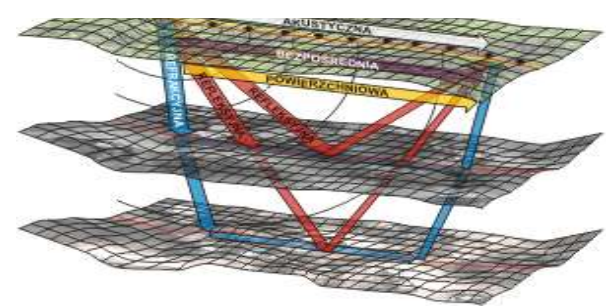

Fig. 8. Visualization of seismic method [22]

\subsection{Ground penetrating radar method (GPR)}

The method relies on the dispersion of electromagnetic waves in the formation. The waves area subjected to various phenomena when passing through a heterogeneous formation, e.g.: breaking, reflection, diffraction.

The analysis of disturbances in the reflected signal allow for locating objects as well as the observation of structural changes in the formation. The ground penetrating radar method is applied to identify geological and geotechnical borders, the settling of soil, voids, identifying underground structures, searching for infrastructure, such as cables, pipes (also PVC) or collectors [22].

\subsection{Electrical resistance method}

The method relies on analyzing the dispersion of electrical current in the analyzed formation; it is based on determining changes in the physical parameter of the analyzed soil, such as the proper electrical resistance (resistivity). These changes are induced by objects of a natural (geological) origin, as well as being anthropogenic (resulting from human activities). The electrical resistance method is applied to indicate geological and geotechnical borders (e.g. directional drillings - HDDs), determining the resistivity of the land (e.g. for gas pipelines), searching for changes in the resistance of the soil, level of water, searching for the extent of contamination, pollutions, identifying underground objects [22].

\subsection{Microgravimetric method}

The method is based on the analysis of changes in the gravitational pull, generating micro abnormalities of gravitation attraction, which are caused by the heterogeneous distribution of rocks in the rock mass. The microgravimetric method is applied to determine the loosenings and areas of weakened substratum, and, above all, indicating voids. This is most often the location of "travelling" voids, which result from shallow mining and karst phenomena, detecting nondocumented mining shafts, bootleg mines, minor shafts, and adits. In addition to mining excavations, these are, i.a., residential rooms, utility as well as military rooms, fortifications, cellars, chambers, tunnels and corridors, as well as 
underground objects of religious worship in the form of catacombs, crypts or tombs [22].

\subsection{Electromagnetic method}

This method involves the analysis of the disturbance of an induced electromagnetic field in the medium. Analyses of disturbances in the reflected signal give the possibility of locating objects. The electromagnetic method is applied to detect changes in the soil resistivity, establish the contours of the extent to soil contamination and pollution, localize areas of increased filtration or seepage, and detect underground structures, collectors and tunnels.

\section{SELECTED METHODS OF LOCATING SEWAGE PIPES AND STUDIES OF THE SOIL MEDIUM IN THEIR PROXIMITY}

Generally speaking, we can claim that geophysics is a study dealing with research on the physical characteristics of the Earth's crust. These features are described by flexibility, electric, magnetic and electromagnetic, radioactive and gravimetric and thermal. In measurements of the physical properties of land space, geophysics makes use of essentially natural or excited physical fields. In addition to the groups as seen above, the electromagnetic method in its reflective version (GPR - Ground-Penetrating Radar) was also distinguished.

Non-invasive methods for studying the soil medium also include geophysical methods in which research is carried out from the surface of the land, in addition to using the existing exploratory wells, the method of drilling geophysics is distinguished [10].

Among the currently most frequently applied methods of locating pipes or cables, variants of methods making use of the properties of electromagnetic waves ought to be distinguished. Essentially, the space between an underground pipe or cable and the surface of the terrain on which the measurement equipment is located is examined under the framework of measurement works. When detecting metal cables and pipes, methods of an induced electromagnetic field are applied alternating current which creates an electromagnetic field around the cable is activated in a cable found beneath the land surface. It is registered by the receiver and subjected to analysis. Induced electromagnetic field methods can be divided into active and passive ones. The passive methods make use of the natural activation of current flow in cables by stray currents, the source of which may be, e.g. electric cables running nearby. Also in the case of very low frequencies of long waves sent out by radio transmitters (in a range from 15 to $25 \mathrm{kHZ}$ ), metal pipes serve as appropriate antennas, allowing for their localization. In active localization, the electromagnetic field in the sought cable is artificially induced by 
the person carrying out the studies. Induction may occur from the surface of the terrain using a transmitter (induced connection - pulse metal detector frame coil).

\section{UNDERGROUND INFRASTRUCTURE AS A FACTOR REGULATING SPATIAL ORDER AND URBAN LAYOUTS}

The location of development which ought to be reached by underground infrastructure indicates the necessity of setting aside areas intended for transportation (access to real estate). Technical installations (water and sewage, electrical and gas connects, etc.) supplying buildings are most often located in these transport routes. In accordance with the applicable laws in force, there are guidelines according to which proper distances ought to be maintained so that, in the case of failure of any of the connections of the underground installation, it is possible to safely remedy the damage, while not allowing other utilities existing in the ground to be damaged [11],[12]. The new roads which are being created as a result of the spatial development of urbanized areas create a publically available communication and transportation network [Fig.9]. Infrastructure constructed in such layouts, creates a network of underground installations of significant throughput and flows, generating increasingly greater diameters of pipelines supplying and removing municipal sewage and oftentimes even industrial sewage [13].

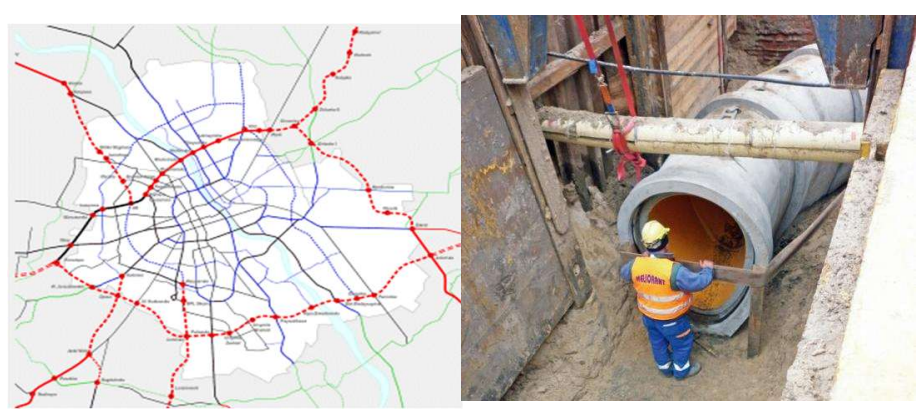

Fig. 9. New inner-city transportation routes [23]

Fig. 10. New large-diameter installation infrastructure [24]

Planning new neighborhoods intended for development therefore ought to be based on first planning infrastructure indicating the technical corridors equipped with complete various kinds of underground installations as well as strips of the land planned as reserves for the potential construction of additional unities in the area, and not will not be possible to plan the urban arrangements abiding by all kinds of regulations, guidelines and tendencies using various types of conceptual 
programming, e.g. by announcing urban planning competitions, until such areas are designated and accounted for [Fig.10].

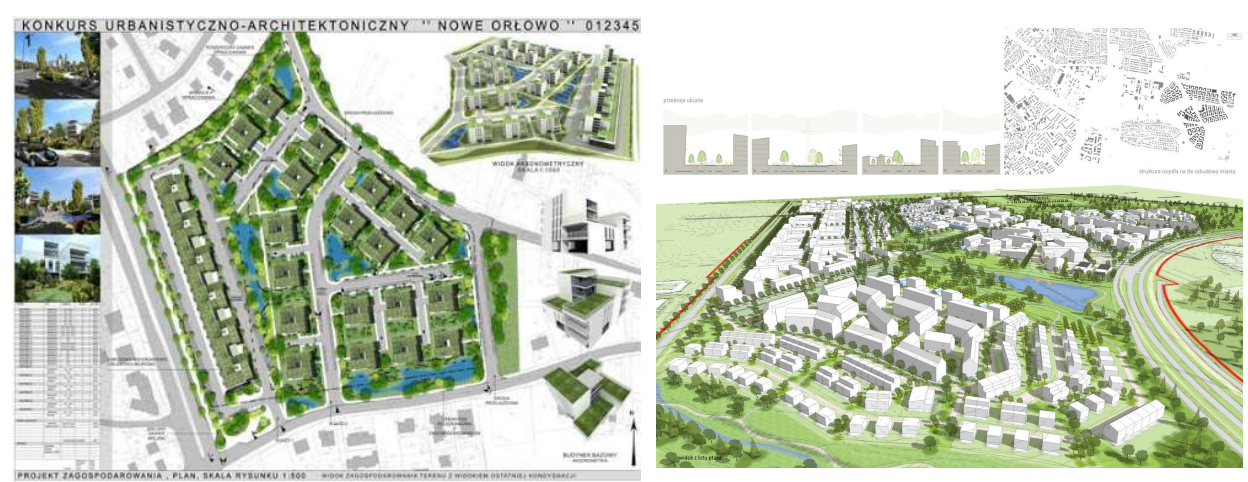

Fig. 11. Sample of urban compositions [25]

Fig. 12. Visualization of urban planning concept [25]

In such designated courses of technical corridors it will be possible to successively introduce new types of installations, e.g. structured cabling used for managing already existing or newly-designed IT infrastructure[Fig.11]. An example of this type of cable installation infrastructure is a network of signaling, alarm and warning systems, Building Management Systems (BMS) - intelligent systems for building management, CCTVIP television (VvolP), and digital ISDN telephony and multi-media transmissions within the network [Fig12].

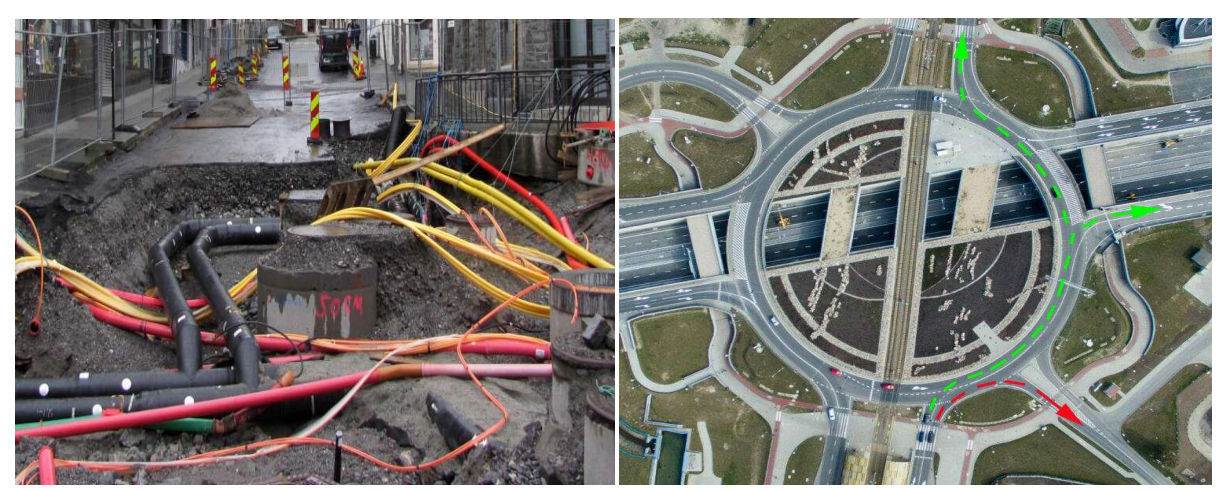

Fig. 13. Location of cables and pipes of underground integrated installations introduced into existing development [26]

Fig. 14. Complex transportation network of modern-day urbanized areas equipped with an interdisciplinary infrastructure network [27] 
Failure to provide such free areas of land leads to difficulties, in many cases eliminating the possibility of introducing new types of infrastructure in a highly invested area [Fig13].

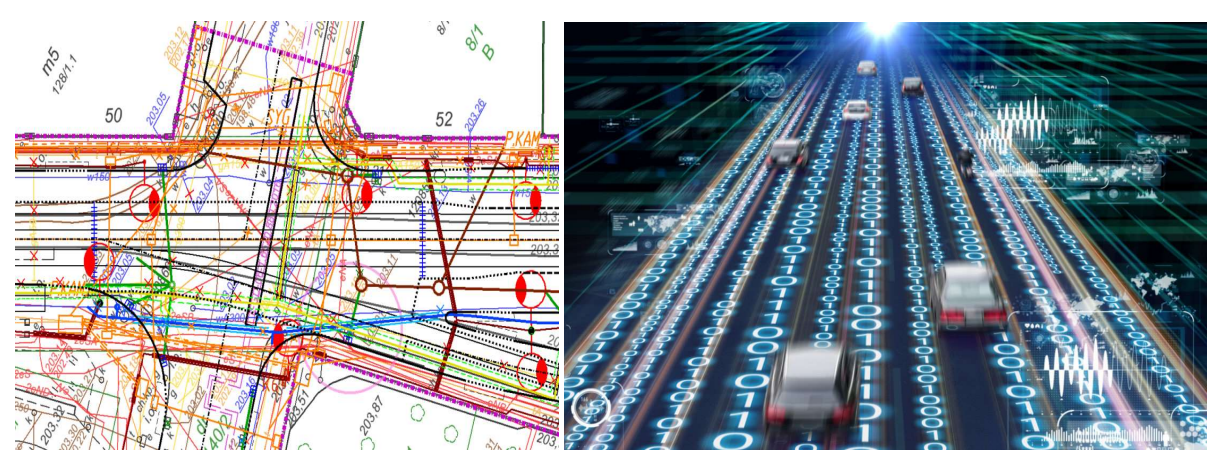

Fig. 15. Current transportation areas intensively built-up with underground infrastructure

Fig. 16. Modern principle of setting out the course of cables and pipes of underground infrastructure in BIM technology [28]

Spatial planning based on modern techniques of identifying utilities of an area as well as integrated BIM design systems allow for obtaining a high level of information as well as visualizing such information [14], [Fig.14]. The current principles of spatial planning comprise new knowledge, while their comprehensiveness determines the results of their application - the effects [15], [Fig.15].

\section{FINAL CONCLUSIONS}

As a result of the revitalization of physical space in urbanized areas, the planning process ought to be elaborated to include compulsory non-invasive spatial analyses of land space, which usually hides the remains of historically-shaped physical technical-structural transformations. Current, modern and continuously developing research techniques, which include geophysical identification methods, ought to be introduced as the standard procedure for establishing the scope of design-realization works specified at the level of building projects, which ought to be in accordance with the urban-planning conditions described by way of a decision on land development and management conditions or in a local spatial development plan, using modern identification techniques [16]. As of now, no standardization literature has been noted in the form of a methodological guidebook or instructions formulating the rules and guidelines for indicating the issue of the cultural environment as well as making use of areas for other utility functions in local spatial development plans of communes in parts formulating the 
general and detailed considerations. Each problem should be studied ad addressed in as comprehensive of manner as possible. Underestimating the studies or drawing conclusion too quickly results in improper planning decisions, problems with using the area or devastation of the landscape. This can consequently result in the possibility of difficulties arising in the realization-administrative processes when dealing with the management of underground technical infrastructure which has been historically exploited and currently not inventoried

\section{REFERENCES}

1. Bonenberg, $\mathrm{W} 2005$. The research aspect in the revitalization process (Aspekt badawczy $w$ procesie rewitalizacji) W: Bonenberg, W, Baczyński, K Rewitalizacja miast (ed). Politechnika Poznańska, Poznań, 79- 90.

2. Bonenberg, W 2007. Creative urban space (Miejska przestrzeń kreatywna). Architektura i Urbanistyka, Zeszyty Naukowe Politechniki Poznańskiej nr 10, Poznań.

3. Degórski, M 2005. Landscape as an objective visualization of phenomena and processes taking place in the mega-system of the geographical environment (Krajobraz jako obiektywna wizualizacja zjawisk i procesów zachodzacych w mega systemie środowiska geograficznego) W: Krajobraz kulturowy. Aspekty teoretyczne i metodyczne, red. Myga-Piątek U., Prace Komisji Krajobrazu Kulturowego PTG nr 4, Komisja krajobrazu Kulturowego PTG, Sosnowiec 2005, 13-25.

4. Ksit, B and Pilch, R 2019. Liquid plastic films as a solution in terms of brightness problems and problems aesthetics improvement review. Budownictwo i Architektura 18(4), 51-58.

5. Laks, I, Walczak, Z, Szymczak-Graczyk, A, Ksit, B and Mądrawski, J 2018. Hydraulic and legal conditions for buildings in floodplains-case study of Kalisz city (Poland). Web Of Conferens Praga 2018.

6. Szymczak-Graczyk, A, Laks, I, Ksit, B and Ratajczak, M 2021. Analysis of the Impact of Omitted Accidental Actions and the Method of Land Use on the Number of Construction Disasters (a Case Study of Poland). Sustainability 13(2): 618.

7. Nowogońska, B and Korentz, J 2021. Value of Technical Wear and Costs of Restoring Performance Characteristics to Residential Buildings. Building s $10(1), 9$.

8. Nowogońska, B and Cibis, J 2017. Technical problems of residential construction World Multidisciplinary Civil Engineering - Architecture Urban Planning Symposium - WMCAUS 2017. Prague, Czechy, 2017, IOP Publishing, 2017, IOP Conf. Series: Materials Science and Engineering, Vol. $245,1-6$. 
9. Pilch, R and Borowski, K 2003. Urban and architectural aspects of recreational development in protected areas on the example of the Nadgoplanski Tysiąclecia Park (Urbanistyczno-architektoniczne aspekty zabudowy rekreacyjnej $w$ obszarach chronionych na przykładzie Nadgoplańskiego Parku Tysiąclecia) W: Wydawnictwo Jubileuszowe XXXlecia Kierunku Architektura i Urbanistyka na Politechnice Poznańskiej, w. Politechniki Poznańskiej, Poznań.

10. Pilch, R 2008. Characteristic elements of modern construction art (Charakterystyczne elementy współczesnej sztuki budownictwa). W zbiorze ARS Architektura, Urbanizm, Studia Wyższej Szkoły Gospodarki w Bydgoszczy, Instytut Architektury i Urbanistyki, UNESCO, MAN AND THE BIOSPHERE, URBAN SYSTEM MAB-11 [red]: Zimowski, L, Polska Akademia Nauk Oddział w Poznaniu. Komisja Urbanistyki i Planowania Przestrzennego w: COMPRINT, Poznań.

11. Pilch, R 2018. Selected issues of spatial planning in the context of the existing infrastructure and underground structures of urbanized areas (Wybrane zagadnienia planowania przestrzennego w kontekście istniejącej infrastruktury i budowli podziemnych obszarów zurbanizowanych). Przeglad Budowlany Nr 7-8/2018. Warszawa.

12. Rösler, H, Bönisch, E, Schopper, F, Raab, T and Raab, A 2012. Preindustrial charcoal production in southern Brandenburg and its impact on the environment $\mathrm{W}$ : Landscape Archaeology between Art and Science, [red.] Kluiving, S, Guttmann-Bond, E, Amsterdam, 167-178.

13. Trier, ØD, Zortea, $M$ and Larsen, SØ 2012. Semi-automatic detection of burial mounds in forested areas In: European Association of Remote Sensing Laboratories. 32nd EARSeLSymposiumProceedingsAdvances in Geosciences.

14. Wężyk, P 2006. Introduction to laser scanning technology in forestry (Wprowadzenie do technologii skanowania laserowego w leśnictwie), Rocznik Geomatyki 4/4, 119-132.

15. Wysocki, G and Ksit, B 2015. Facility condition assessment of a livestock building and a proposal of optimalization of renovation of the rafter framing Trwałe metody naprawcze w obiektach budowlanych [red.] Błaszczyński, T. Dolnosląskie w. edukacyjne, 239-246.

16. Zapłata, R 2013. Sprawozdanie cząstkowe $\mathrm{z}$ badań nieinwazyjnych przeprowadzonych w III/IV kwartale 2012 r. oraz I kwartale 2013 r. na terenie Leśnictwa Seredzice oraz Polany (część S). Projekt naukowy pt. „Zastosowanie skaningu laserowego oraz teledetekcji w ochronie, badaniu i inwentaryzacji dziedzictwa kulturowego. Opracowanie nieinwazyjnych, cyfrowych metod dokumentacji i rozpoznawania zasobów dziedzictwa 
architektonicznego i archeologicznego", [maszynopis w archiwum UKSW oraz WMKZ - Radom], Warszawa.

17. http://skztp.ietu.katowice.pl/

18. https://log24.p1/news/brownfield-rozbiorki-starych-konstrukcji poprzemyslowych-pod-nowe-parki-miejskie/

19. http://www.instsani.pl/130/wlasciwosci-fizyczne-i-mechaniczne-gruntowbadania-gruntow

20. http://www.tylkobieszczady.pl/wp-content/uploads/2016/06/04-MGR-2784 $31-2016 . p d f$

21. https://www.fachowyelektryk.pl/technologie/porady-fachowegoelektryka/2204-lokalizacja-uzbrojenia-podziemnego-jak-uniknackolizji.html

22. https://geospectrum.pl/pl/badania-geofizyczne/sejsmiczne/

23. http://siskom.waw.pl/drogi-miejskie.htm

24. http://www.doraco.pl/portfolio/kolektor-sanitarny-morena-w-gdansku/

25. https://pl.pinterest.com/pin/365073113525077851/

26. https://geoforum.pl/news/25826/

27. https://trojmiasto.wyborcza.pl/trojmiasto/51,35612,19907429.html?i=2

28. https://inzynierbudownictwa.pl/geobim-czyli-geotechnika-w-bim

Editor received the manuscript: 21.04.2021 